\title{
HEALTH CARE SPENDING STRUCTURES IN POLAND, LATVIA, LITHUANIA AND ESTONIA OVER THE YEARS AS COMPARED TO OTHER EU COUNTRIES
}

\author{
Renata WALCZAK*, Marlena PIEKUT**, Magdalena KLUDACZ-ALESSANDRI*** \\ Warsaw University of Technology, College of Economics and Social Sciences, Plock, POLAND \\ e-mails: \{*renata.walczak,** marlena.piekut,***magdalena.kludacz\}@pw.edu.pl \\ Biruta SLOKA \\ University of Latvia, LATVIA \\ e-mail: biruta.sloka@lu.lv \\ Ligita ŠIMANSKIENE \\ Klaipeda University, LITHUANIA \\ e-mail: ligita.simanskiene@gmail.com \\ Tiiu PAAS \\ Tartu University, ESTONIA \\ e-mail: Tiiu.Paas@ut.ee
}

\begin{abstract}
After joining the European Union in 2004, the post-communist countries have dramatically changed their structure of expenditure for medical services. The cause of this is legislative and ownership changes in the new economy. The study analyzed the expenditure on medical services in the European Union with a special focus on Poland, Latvia, Lithuania and Estonia. The European Union countries were divided into clusters using different methods, that is, Ward's, Two Step and Centroid Clustering. In the paper, the structure and changes in health expenses were presented according to the types of expenditures over the years 2004-2015. Countries were assigned to clusters based on three variables: medical products, appliances and equipment, outpatient services and hospital services. Variables were considered as a percentage of household budget. In Lithuania, Latvia and Estonia, there is a clear increase in the outpatient services spending compared to the hospital services expenditure.
\end{abstract}

Keywords: consumption, households, health, structure of expenditures.

JEL: H44, I11.

\section{Introduction}

Health is one of the basic needs of every society. Life expectancy has increased in all the European Union countries since the seventies, and the society needs a broader health care. European Union countries have changed the structure of expenditures for medical products and services in recent years. The possible causes are legislative and ownership changes in the new economy.

In the European Union, the health care expenses varied significantly. In 2008, in selected countries like Germany and France, the total health care spending has exceeded $10 \%$ of GDP, while in Romania and Estonia the level of $6 \%$ was achieved. Taking into account spending per capita, the differ- ence is more visible. In 2016, the share of GDP devoted to health care in Poland, Latvia, Lithuania and Estonia was below the European Union average (Table 1, Fig.1), however, private spending was similar to the European average. Generally, health expenditure was lower in countries with centralized health care systems where private social insurances were limited. There are two main health care models in the European Union, insurance - Bismarc's and state - Beverige's. In the insurance system, the main source of funding is the compulsory contributions of insured persons. In some systems (i.e., France, Belgium and Luxembourg), insured persons have the right to choose a health care service provider and the costs are covered from the system. In Holland, Austria and Germany, the health care is free of charge. 


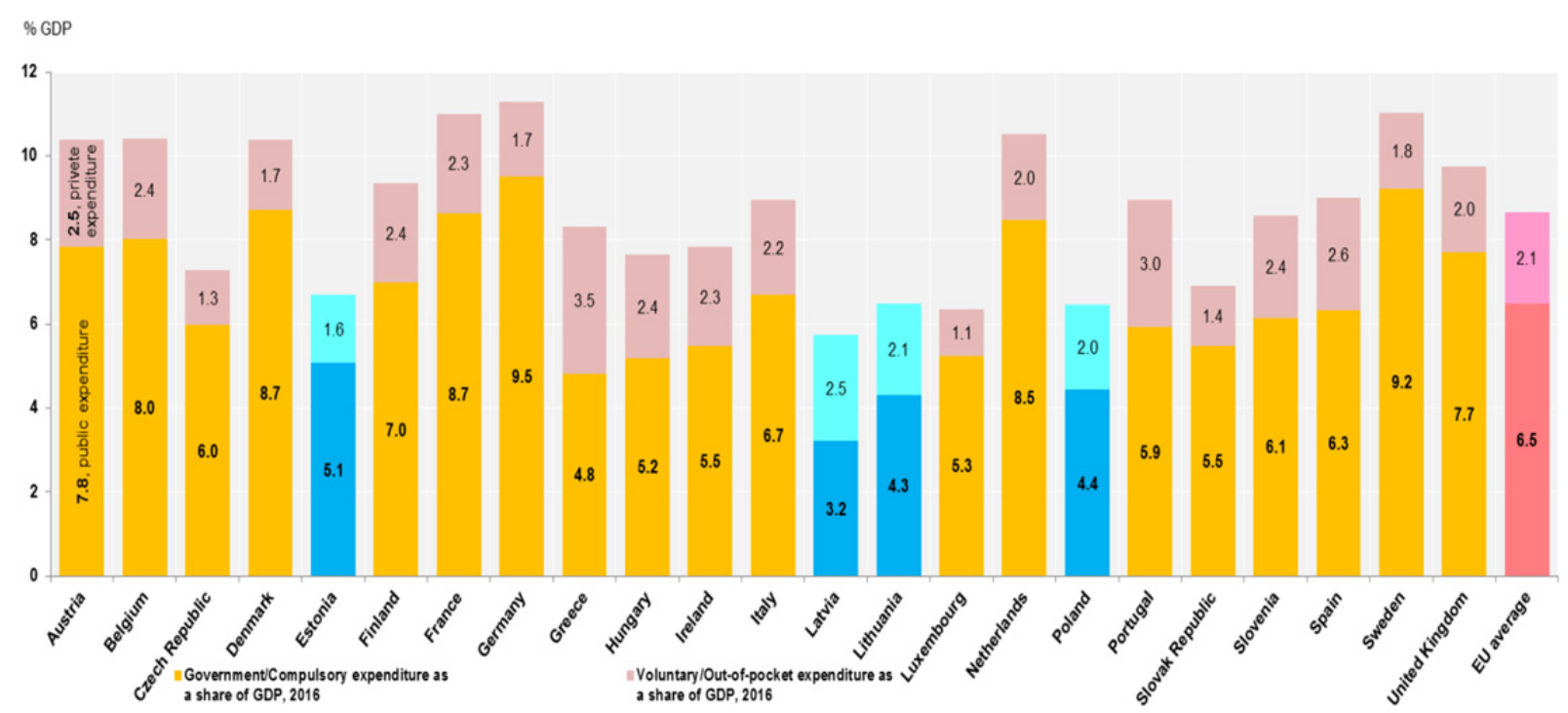

Figure 1. Health expenditure in 2016 in the European Union as a share of GDP (Source: Own work based on data from WHO Global Health Expenditure Database, OECD, 2017; World Health Organization, 2017)

Compulsory insurance systems offer only basic health care, and over-standard services are provided under supplementary insurance.

The Beverige's system is organized by state and financed from taxes, where everybody can use health services equally. In Greece, Spain, Portugal and Ireland, health care is organized by state, while in Denmark, Finland and Sweden, local authorities are responsible for health care (Głąbicka, 2012). There are several aspects analyzed in academic research on private and public spending issues (Przekota, Lisowska, 2016). Aspects of health care spending are on research agenda world-wide (Tran, et al, 2017; Mays, Mamaril, 2017; Yu, et al., 2017; Chen, et al., 2017; Szczepańska, Wiśniewska, 2012).

Before 2004, when Poland, Latvia, Lithuania and Estonia entered the European Union, the public health care systems in these post-soviet countries were under state supervision. Lithuania, Latvia and Estonia regained independence from Russia in 1990s. Until 1989, Poland was also under the Russian influence. Since then, the economies of these countries, their political rules, societies and health care systems have undergone significant changes.

In Poland, before 2004, the Ministry of Health Care was responsible for the health care strategy. Postcommunist centralized system was gradually changed into a new one, where the state and local authorities were responsible for financing the health services. At present, the National Health Fund has taken over this function. In 2016, 69\% health care spending (6.4 GDP) came from public funds, from mandatory insurance covering $98 \%$ of the population (Table 1, Fig.1). Large part of the remaining expenditure was incurred by households, mainly for purchasing medicines and private health services. In 2015 , three fourth of the private expenditure came from household budgets (Table 2) (Eurostat, 2017). Private supplementary health insurance do not play a significant role in the health care financing and is mainly limited to medical packages offered by employers (World Health Organization, 2011). In Poland, most hospitals are public, however, medical centers and ambulatories belong to private owners. Basic medical care is free of charge for those who pay insurance fees. Over-standard care is limited and the waiting list system allows access to specialist care. Due to long queues, wealthier patients can afford extra paid private health care. In order to reduce waiting time in public health care system, patients pay bribes to doctors responsible for medical procedures in the public health organizations. Unfortunately, these payments are not listed in official health services statements (European Commission, 2013).

In Latvia, before 2004, the Ministry of Health and the Public Health Agencies established the health care policy. 
Table 1. Health expenditure in 2016 in selected European Union countries (Source: Own work based on data from WHO Global Health Expenditure Database,

OECD, 2017; World Health Organization, 2017)

\begin{tabular}{|c|c|c|c|c|c|}
\hline EU Country & $\begin{array}{l}\text { Total health } \\
\text { expenditure } \\
\text { as a share } \\
\text { of GDP, } 2016\end{array}$ & $\begin{array}{c}\text { Government } \\
\text { /Compulsory } \\
\text { expenditure } \\
\text { as a share } \\
\text { of GDP, } 2016\end{array}$ & $\begin{array}{c}\text { Voluntary } \\
\text { /Out-of-pocket } \\
\text { expenditure } \\
\text { as a share } \\
\text { of GDP, } 2016\end{array}$ & $\begin{array}{l}\text { Public } \\
\text { expenditure } \\
\text { rate }\end{array}$ & $\begin{array}{l}\text { Private } \\
\text { expenditure } \\
\text { rate }\end{array}$ \\
\hline Austria & 10.4 & 7.8 & 2.5 & $75.7 \%$ & $24.3 \%$ \\
\hline Belgium & 10.4 & 8.0 & 2.4 & $77.3 \%$ & $22.7 \%$ \\
\hline Czech Republic & 7.3 & 6.0 & 1.3 & $82.4 \%$ & $17.6 \%$ \\
\hline Denmark & 10.4 & 8.7 & 1.7 & $84.0 \%$ & $16.0 \%$ \\
\hline Estonia & 6.7 & 5.1 & 1.6 & $76.1 \%$ & $23.9 \%$ \\
\hline Finland & 9.3 & 7.0 & 2.4 & $74.8 \%$ & $25.2 \%$ \\
\hline France & 11.0 & 8.7 & 2.3 & $78.8 \%$ & $21.2 \%$ \\
\hline Germany & 11.3 & 9.5 & 1.7 & $84.6 \%$ & $15.4 \%$ \\
\hline Greece & 8.3 & 4.8 & 3.5 & $58.3 \%$ & $41.7 \%$ \\
\hline Hungary & 7.6 & 5.2 & 2.4 & $68.3 \%$ & $31.7 \%$ \\
\hline Ireland & 7.8 & 5.5 & 2.3 & $70.2 \%$ & $29.8 \%$ \\
\hline Italy & 8.9 & 6.7 & 2.2 & $75.0 \%$ & $25.0 \%$ \\
\hline Latvia & 5.7 & 3.2 & 2.5 & $56.4 \%$ & $43.6 \%$ \\
\hline Lithuania & 6.5 & 4.3 & 2.1 & $67.0 \%$ & $33.0 \%$ \\
\hline Luxembourg & 6.3 & 5.3 & 1.1 & $83.0 \%$ & $17.0 \%$ \\
\hline Netherlands & 10.5 & 8.5 & 2.0 & $80.8 \%$ & $19.2 \%$ \\
\hline Poland & 6.4 & 4.4 & 2.0 & $69.0 \%$ & $31.0 \%$ \\
\hline Portugal & 8.9 & 5.9 & 3.0 & $66.2 \%$ & $33.8 \%$ \\
\hline Slovakia & 6.9 & 5.5 & 1.4 & $79.8 \%$ & $20.2 \%$ \\
\hline Slovenia & 8.6 & 6.1 & 2.4 & $71.8 \%$ & $28.2 \%$ \\
\hline Spain & 9.0 & 6.3 & 2.6 & $70.6 \%$ & $29.4 \%$ \\
\hline Sweden & 11.0 & 9.2 & 1.8 & $83.9 \%$ & $16.1 \%$ \\
\hline United Kingdom & 9.7 & 7.7 & 2.0 & $79.2 \%$ & $20.8 \%$ \\
\hline EU average & 8.6 & 6.5 & 2.1 & $75.2 \%$ & $24.8 \%$ \\
\hline
\end{tabular}

Ten regional health centers and municipalities took care of the health care in each district. County and municipal doctors' importance was diminished steadily to state agencies.

Low income patients were supported by local governments which reimbursed their health care expenses (World Health Organization, 2011). The system has been significantly changed since 2017 . Health care is coordinated by the Ministry of Health and is financed from taxes, direct payments and voluntary insurance. $5.7 \%$ of GDP is intended for health care. $56.4 \%$ come from state funds, $43.6 \%$ is incurred from private sources (Table 1, Fig. 1) (OECD, 2017), $85 \%$ of the latter are incurred by households (Eurostat, 2017). Basic services are free of charge for everybody. Over-standard services are a subject 
of additional insurance. As everywhere, corruption in health care is ubiquitous and is not stated in official statements (Mitenbergs, Brigis and Quentin, 2014; European Commission, 2013).

Before Lithuanian entrance to the European Union, the Ministry of Health and the State Public Health Services were responsible for public health strategy. County and municipal doctors, who were responsible for health care in individual regions, were under public health agencies supervision. All medical services were officially free of charge. Now, only the basic health services are unpaid. In 2016, 6.5\% of Lithuanian GDP was spent on health care (Fig.1), two thirds was financed from state funds and patients' mandatory insurance by the National Health Insurance Fund, one third was covered by patients from their budgets for medicines, medical products, appliances, equipment and over-standard services (Table 1, Table 2) (Eurostat, 2017). In Lithuania, in parallel with public health care institutions, private providers offer paid services. In state organizations, doctors expect bribes to treat patients well. Unfortunately, informal payments are not officially documented (European Commission, 2013).

In Estonia, the Ministry of Social Affairs and the National Institute for Health Development determined care strategy. Municipal and county health care councils were responsible for organizing health care. Over time, these organizations had less responsibilities and were taken over by the County Health Protection Inspectorate and Labor Inspectorate (O'Connor and Bankauskaite, 2008). Now, the Ministry of Social Affairs takes care of the centralized health care system. In 2016, 6.5\% of Estonian GDP was spent on health care (Fig.1), 56.4\% came from state funds and from mandatory social insurance, $43.6 \%$ was covered from patients' private funds (Table 1); $92 \%$ from households resources (Eurostat, 2017). Private health care expenditure in Estonia was $50 \%$ lesser than in Poland, Lithuania and Latvia. Most types of health care services are private in Estonia, only the most expensive services are centralized and are under public supervision. In hospitals, patients pay for health services according to the Diagnosis Related Groups rules and regulations. Like in Poland, patients pay bribes for quicker access to specialist care, for additional services, for skip- ping the queues, and similar to Poland and Lithuania, these costs are not recorded in official statements (European Commission, 2013).

The aim of the research is to identify households' expenditures on medical products and services in the European Union in the period 2004-2015, with special focus on Poland, Latvia, Lithuania and Estonia. Year 2016 was not taken into account due to the lack of data in the WHO Global Health Expenditure Database. Aforementioned countries may still suffer from their post-socialist legacy in organizing social services and particularly in providing health care services. More than 10 years' experience of collaboration within the EU system and following the general requirement for the development of health services in the European Union put these countries in quick reorganization of their health care systems. Supposing, the reorganization patterns have been somewhat different in all countries, and consequently, also the structure of expenditure on medical service and products changed differently country by country. These developments may provide some lessons for reorganization processes and for identifying possible best practices. Thus, the results of the study can provide additional information for the development of and restructuring of the health care systems as well as for generating ideas for crosscountry cooperation in health care and for the development of sustainable expenditure patterns.

Only officially recorded expenditure was taken into account. Illegal payments, even though high, were not considered. According to the European Commission research, a large part of the economies of Poland, Latvia, Lithuania and Estonia (about one third) remain in the grey area. In the literature, there are no household spending comparisons for those countries; which started in similar conditions and now all of them suffer from large share of informal economy (European Commission, 2013).

Based on this objective, three research issues were identified:

1) presenting the share of health expenditure in the total spending and the structure of expenditure of households from Latvia, Lithuania, Estonia and Poland as compared to the other European Union countries in 2004 and 2015; 
Table 2. Household total health care payments as a share of GDP (Source: Own work based on data from: Eurostat, 2017)

\begin{tabular}{|c|c|c|c|c|c|c|c|c|c|c|c|c|}
\hline EU Country & 2004 & 2005 & 2006 & 2007 & 2008 & 2009 & 2010 & 2011 & 2012 & 2013 & 2014 & 2015 \\
\hline Austria & $:$ & $:$ & $:$ & $:$ & $:$ & $:$ & $:$ & 1.77 & 1.81 & 1.86 & 1.86 & 1.85 \\
\hline Belgium & 1.71 & 1.63 & 1.67 & 1.72 & 1.73 & 1.84 & 1.82 & 1.85 & 1.83 & 1.88 & 1.89 & 1.84 \\
\hline Bulgaria & : & $:$ & $:$ & $:$ & $:$ & $:$ & $:$ & $:$ & $:$ & 3.7 & 3.9 & 3.91 \\
\hline Croatia & $:$ & $:$ & $:$ & $:$ & $:$ & $:$ & $:$ & : & : & 0.88 & 1.12 & 1.12 \\
\hline Cyprus & $:$ & $:$ & $:$ & $:$ & $:$ & $:$ & 2.57 & 2.82 & 2.95 & 2.98 & 3.04 & 2.97 \\
\hline Czech Republic & : & : & : & : & : & : & : & : & : & 1.06 & 1.08 & 1.07 \\
\hline Denmark & : & : & : & $:$ & : & : & $:$ & : & $:$ & $:$ & 1.43 & : \\
\hline Estonia & : & : & : & : & 1.19 & 1.33 & 1.39 & 1.26 & 1.25 & 1.36 & 1.4 & 1.48 \\
\hline Finland & 1.5 & 1.52 & 1.58 & 1.55 & 1.58 & 1.72 & 1.77 & 1.73 & 1.74 & 1.8 & 1.8 & 1.88 \\
\hline France & : & : & 0.77 & 0.78 & 0.81 & 0.85 & 0.83 & 0.81 & 0.79 & 0.78 & 0.77 & $:$ \\
\hline Germany & 1.43 & 1.46 & 1.45 & 1.42 & 1.42 & 1.54 & 1.53 & 1.49 & 1.5 & 1.44 & 1.41 & 1.4 \\
\hline Greece & : & : & : & : & : & 2.78 & 2.69 & 2.81 & 2.68 & 2.83 & 2.92 & 2.97 \\
\hline Hungary & : & : & 1.96 & 1.91 & 1.88 & 1.91 & 2.07 & 2.14 & 2.2 & 2.07 & 2.02 & 2.1 \\
\hline Iceland & : & : & : & : & : & : & : & 1.55 & 1.56 & 1.55 & 1.54 & 1.46 \\
\hline Ireland & $:$ & : & : & : & : & : & : & : & : & 1.56 & 1.53 & 1.18 \\
\hline Italy & : & : & : & : & : & : & : & : & 1.94 & 1.95 & 1.99 & 2.05 \\
\hline Latvia & : & $:$ & : & $:$ & : & $:$ & : & : & $:$ & : & 2.14 & $:$ \\
\hline Liechtenstein & : & : & : & $:$ & $:$ & $:$ & : & : & $:$ & 1.32 & 1.37 & 1.46 \\
\hline Lithuania & : & $:$ & $:$ & $:$ & : & 1.97 & 1.88 & 1.83 & 2 & 2.01 & 1.95 & 2.09 \\
\hline Luxembourg & $:$ & $:$ & : & $:$ & $:$ & $:$ & $:$ & 0.67 & 0.69 & 0.67 & 0.66 & 0.64 \\
\hline Netherlands & : & 0.98 & 0.84 & 0.81 & 1.02 & 0.99 & 1.02 & 1.05 & 1.13 & 1.27 & 1.33 & 1.3 \\
\hline Norway & : & : & : & $:$ & $:$ & : & : & 1.34 & 1.3 & 1.3 & 1.34 & 1.42 \\
\hline Poland & : & $:$ & : & $:$ & $:$ & $:$ & $:$ & $:$ & $:$ & 1.51 & 1.45 & $:$ \\
\hline Portugal & 2.14 & 2.2 & 2.3 & 2.33 & 2.41 & 2.43 & 2.41 & 2.51 & 2.63 & 2.45 & 2.5 & 2.48 \\
\hline Romania & $:$ & $:$ & $:$ & $:$ & $:$ & $:$ & $:$ & : & $:$ & 1.05 & 1.02 & 1.05 \\
\hline Slovakia & $:$ & : & $:$ & $:$ & $:$ & $:$ & $:$ & : & $:$ & $:$ & 1.25 & $:$ \\
\hline Slovenia & : & $:$ & : & $:$ & $:$ & $:$ & : & : & $:$ & $:$ & 1.11 & $:$ \\
\hline Spain & 1.7 & 1.69 & 1.65 & 1.65 & 1.74 & 1.75 & 1.87 & 1.92 & 2.07 & 2.16 & 2.24 & 2.22 \\
\hline Sweden & 1.38 & 1.42 & 1.39 & 1.37 & 1.41 & 1.51 & 1.44 & 1.61 & 1.68 & 1.72 & 1.73 & 1.67 \\
\hline Switzerland & $:$ & : & : & $:$ & $:$ & : & 2.76 & 2.8 & 2.99 & 2.91 & 3.04 & $:$ \\
\hline $\begin{array}{l}\text { United } \\
\text { Kingdom }\end{array}$ & : & : & : & : & $:$ & $:$ & : & : & : & 1.46 & 1.44 & 1.46 \\
\hline
\end{tabular}


2) identification of changes in the expenditure structure of the aforementioned countries in the period of 2004 and 2015;

3) grouping the European Union countries according to the households' health care expenditure;

4) generalization of lessons and best practices of health expenditure reorganization processes to overcome possible hindrances coming from the post-socialist legacy and meeting the challenge of aging societies.

The present paper was presented during the $58^{\text {th }}$ International "Scientific Conference on Economics and Entrepreneurship SCEE'2017" organized by Riga Technical University. Extended abstract of this article was published in the Conference Proceedings (Gaile-Sarkane, 2017).

\section{Methodology of Research}

Research data came from Eurostat database (Eurostat, 2017). The study covered years 2004-2015 and the concerned European Union households, with particular attention to Estonia, Latvia, Lithuania and Poland. Besides calculating basic statistics, the European Union countries were divided into clusters based on three variables: "medical products, appliances and equipment", "outpatient services" and "hospital services". The aim of the analysis was to divide the countries representing the households' expenses into meaningful similar clusters. The more the clusters, the smaller they would be and it would be the more difficult to make sense of them. The aim was to find the optimal number of clusters.

Poland, Latvia, Lithuania and Estonia, as post-soviet countries, used to have similar health care systems before 2004. Cluster analysis was used because it was interesting whether those countries would be in one group from the point of view of household spending. It was also interesting to study how the group membership would change over time. It was possible to use neural networks as a classification tool, however, this method needs very large datasets; there were only half a thousand cases in Eurostat database, while neural networks need much more. It was also possible to use other dimensionalityreduction methods, that is, principal components analysis or factor analysis; cluster analysis was cho- sen as the most robust one. Structural Equation Modelling (SEM) method, which offers important cognitive values and can also divide data set into classes, could have also been used; nevertheless, the number of independent variables was very less to prepare an SEM model.

Variables were calculated as a percentage of household budget. Total expenses and per capita expenditure were not considered. Different clustering methods were used, that is, the Ward's method, where the variance analysis approach is used to estimate distances between clusters (Field, Miles and Field, 2013). This method was chosen since it is stable and provides homogeneity of objects within the cluster and heterogeneity between the clusters (Ward, 1963). Beyond Ward's method, K Means, Two Step and Centroid Clustering techniques were applied. Data from 2004 and 2015 were chosen for analysis. The European Union households were grouped into clusters for both years. SPSS and Statistica software were used to perform the analysis.

\section{$3 \quad$ Results}

Expenditure on pharmaceuticals (medicines, medical devices, dietary supplements) is one of the most important costs in every health care system; therefore, the financial resources allocated for this type of health services are particularly important (Szetela, 2016, p.92). Costs of medicines are predominantly covered by patients (i.e., in Poland) due to insufficient level of co-financing from public funds.

During the period of 2004 to 2015, the share of health expenditure in total household expenditure in Estonia, Lithuania and Latvia has remained almost stable; however, the share of health care expenditures of Polish households has increased. Among other EU countries, the largest increase in health expenditure in total expenditure was recorded in Romania, with the largest drop in the Netherlands and Greece. Apart from changes in the share of health expenditure, changes in the spending structure were also recorded. Compared to year 2004, in 2015 Estonian, Latvian and Lithuanian households spend less for medical products, appliances and equipment (Fig. 2), and more for outpatient services (Fig. 3). 
In Latvian households, the health care spending on outpatient services has reached a dominant position. In the budgets of Poles, the share of expenditure on health in total expenditure has increased, however it was the smallest change in the structure of health expenditure among the analyzed Baltic countries. In other EU countries, the biggest changes in the structure of health spending have been observed in Greece and Romania, where the importance of medi- cal products, appliances and equipment and outpatient services have increased. In Luxembourg and Portugal, the importance of outpatient services has grown, however, the spending on medical products, appliances and equipment has decreased. Household expenditure on hospital services remained the same in Estonia, Lithuania and Poland; however, in Latvia, the expenses have increased threefold (Fig. 4).

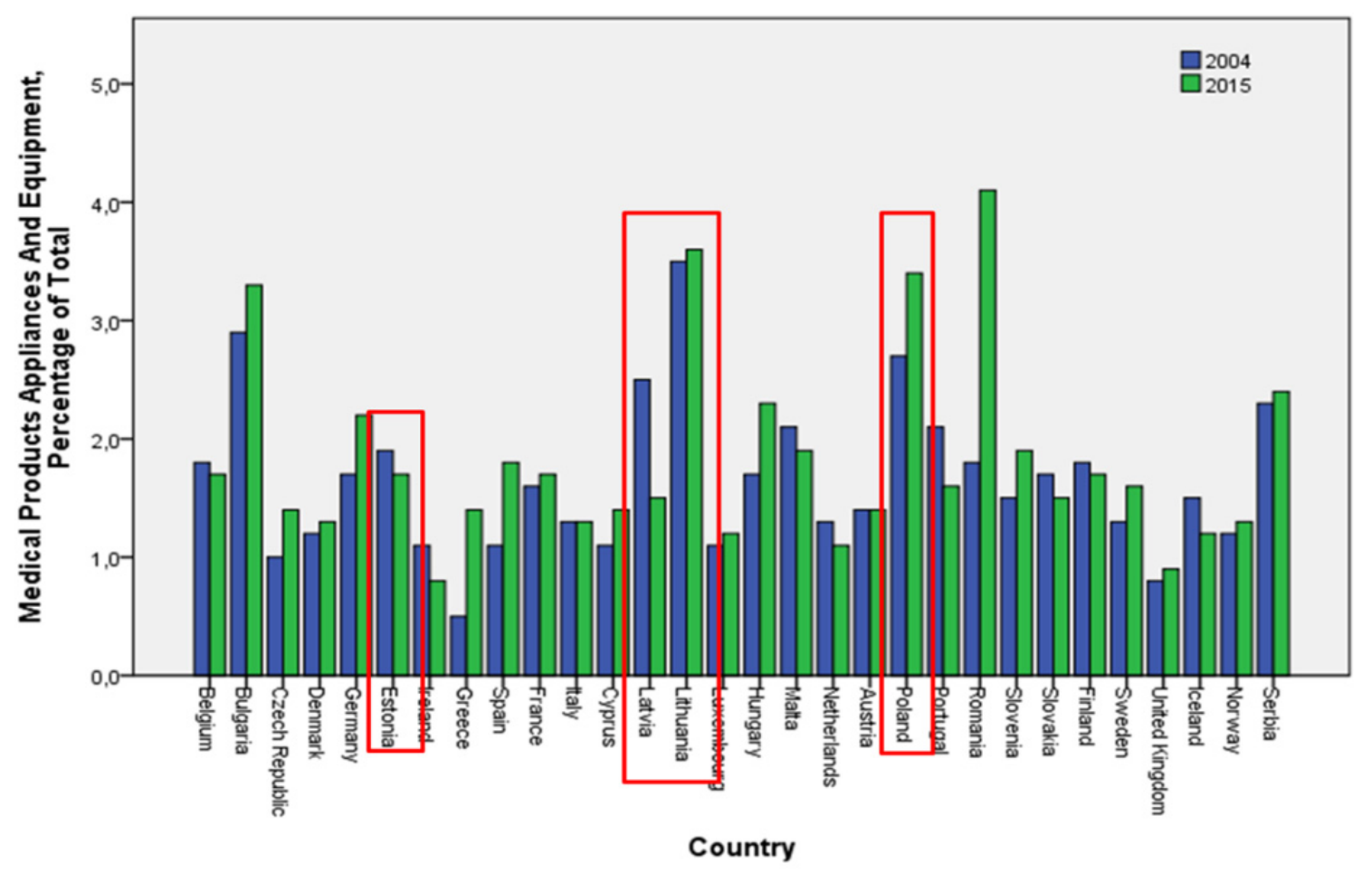

Figure 2. European Union household expenditure on medical products appliances and equipment, as a share of total spending, in 2004 and 2015

(Source: Own work based on data from WHO Global Health Expenditure Database, OECD, 2017; World Health Organization, 2017)

Cluster analysis was performed in order to identify similarities and differences in the structure of EU health expenditure in EU households. The share of health care expenditure in total spending was taken into account to compare all the European Union countries. It was not possible to analyze expenses per capita due to lack of data in the Eurostat Database. Total expenditure was not considered due to the large variation between countries (Eurostat, 2017).

At the outset, Two Step Cluster Analysis was used. The analysis for 2004 did not indicate the existence of significantly different groups. Two to five clusters were created, however the division was not significant, even though the silhouette measure of cohesion and separation for each analysis was good, greater than 0.5 , the largest cluster to the smallest cluster ratio was between 22 and 29, when the expected value should be about 3 to 4 . The smallest clusters included only one or a few countries and the analysis was irrelevant (Table 3).

Analysis for year 2015 showed that four clusters were the best solution (the silhouette measure of cohesion and separation greater than 0.5 , the largest cluster to the smallest cluster ratio $=10$ ). 


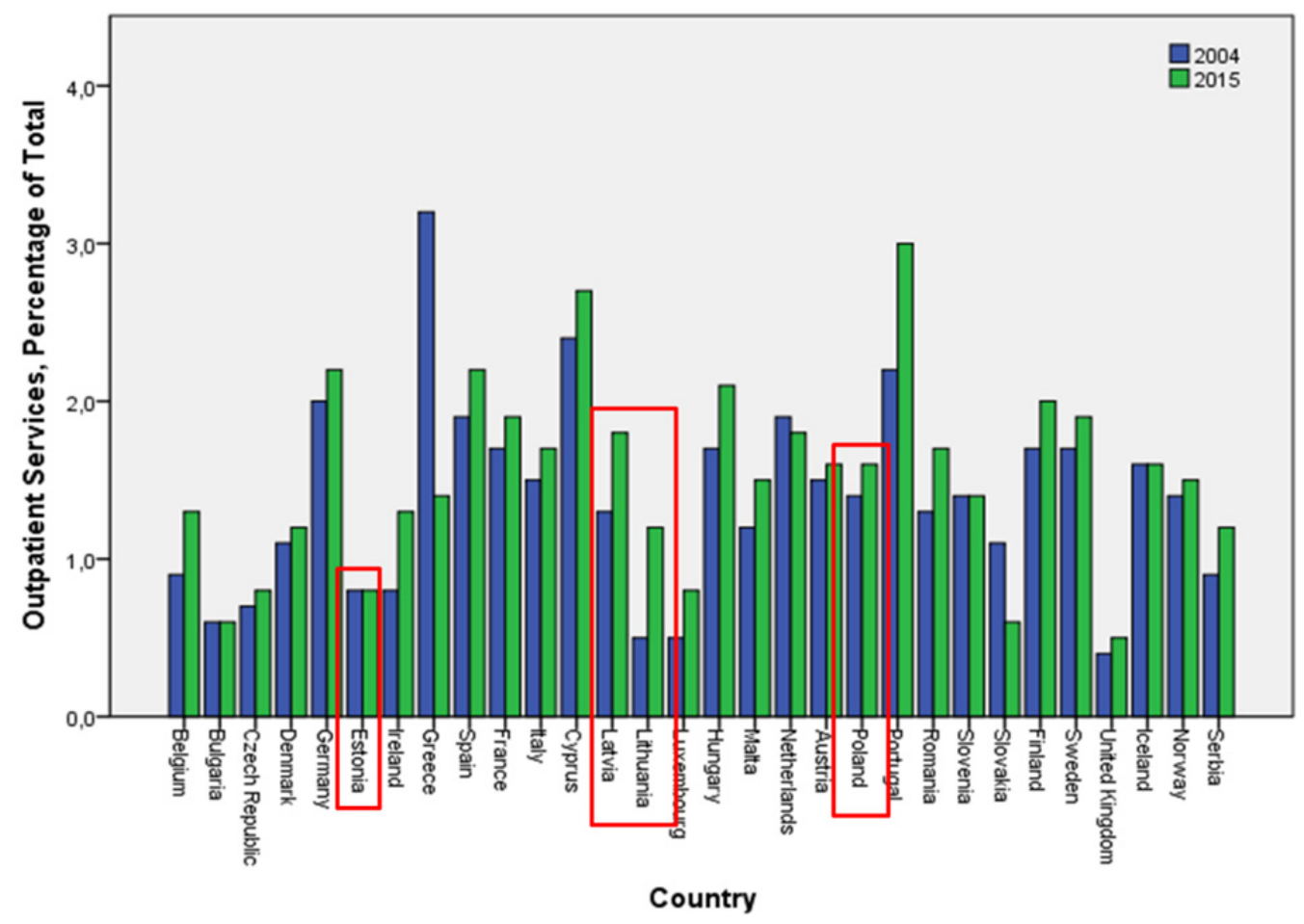

Figure 3. European Union household expenditure on outpatient services, as a share of total spending, in 2004 and 2015

(Source: Own work based on data from WHO Global Health Expenditure Database, OECD, 2017; World Health Organization, 2017)

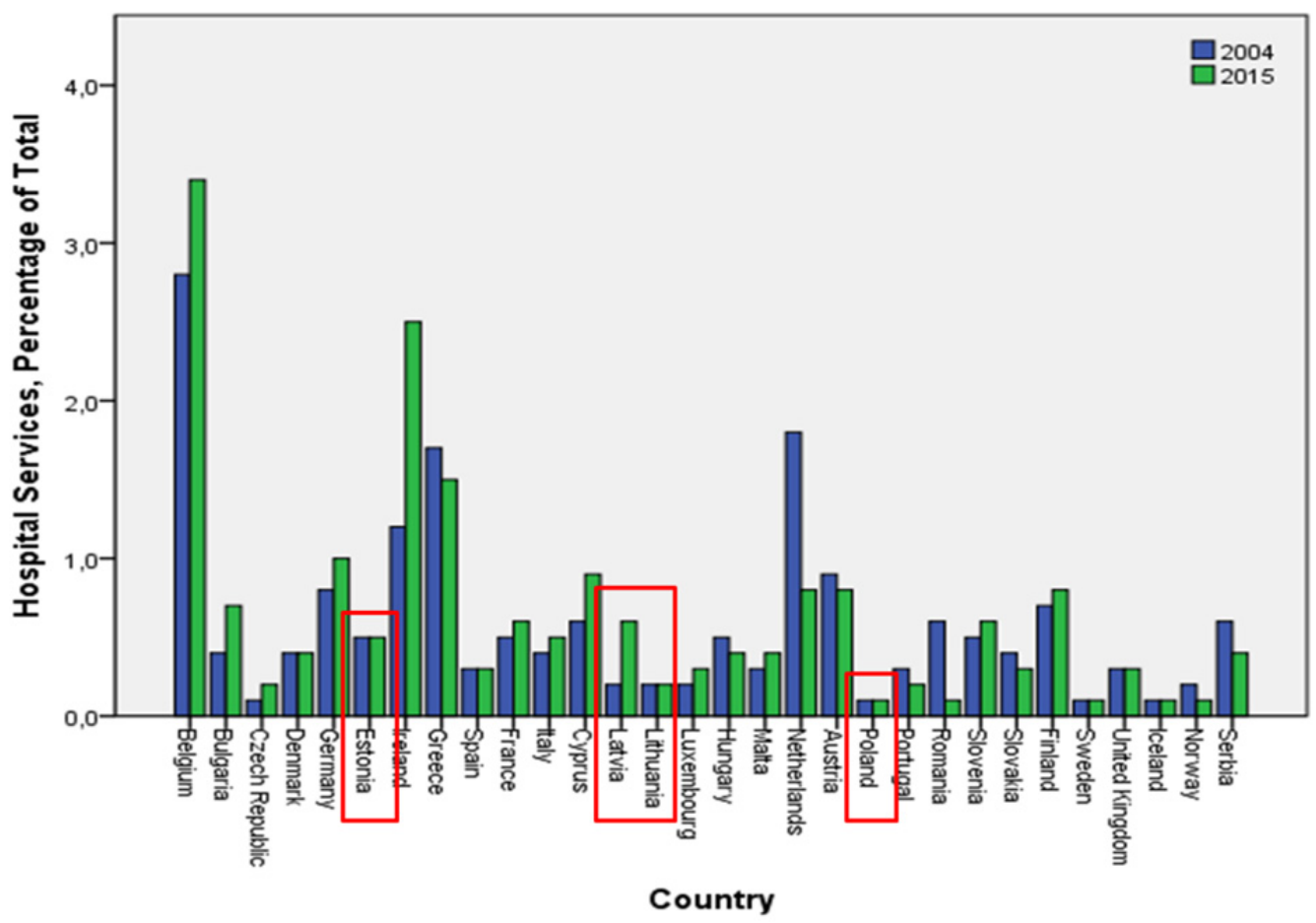

Figure 4. European Union household expenditure, as a share of total spending, on hospital services in 2004 and 2015.

(Source: Own work based on data from WHO Global Health Expenditure Database, OECD, 2017; World Health Organization, 2017) 
Table 3. Cluster membership, Two Step Cluster Analysis results for years 2004 and 2015

(Source: Authors' own research)

\begin{tabular}{|c|c|c|c|c|c|c|c|c|}
\hline \multirow{2}{*}{ UE Country } & \multicolumn{4}{|c|}{2004} & \multicolumn{4}{|c|}{2015} \\
\hline & $\begin{array}{c}2 \\
\text { clusters }\end{array}$ & $\begin{array}{c}3 \\
\text { clusters }\end{array}$ & $\begin{array}{c}4 \\
\text { clusters }\end{array}$ & $\begin{array}{c}5 \\
\text { clusters }\end{array}$ & $\begin{array}{c}2 \\
\text { clusters }\end{array}$ & $\begin{array}{c}3 \\
\text { clusters }\end{array}$ & $\begin{array}{c}4 \\
\text { clusters }\end{array}$ & $\begin{array}{c}5 \\
\text { clusters }\end{array}$ \\
\hline Belgium & 2 & 2 & 2 & 3 & 1 & 1 & 1 & 1 \\
\hline Ireland & 1 & 1 & 1 & 1 & 1 & 1 & 1 & 1 \\
\hline Bulgaria & 1 & 1 & 1 & 2 & 2 & 2 & 2 & 2 \\
\hline Lithuania & 1 & 1 & 1 & 2 & 2 & 2 & 2 & 3 \\
\hline Poland & 1 & 1 & 1 & 2 & 2 & 2 & 2 & 3 \\
\hline Romania & 1 & 1 & 1 & 1 & 2 & 2 & 2 & 3 \\
\hline Germany & 1 & 1 & 1 & 1 & 2 & 3 & 3 & 4 \\
\hline Spain & 1 & 1 & 1 & 1 & 2 & 3 & 3 & 4 \\
\hline Portugal & 1 & 1 & 1 & 1 & 2 & 3 & 3 & 4 \\
\hline Cyprus & 1 & 3 & 1 & 1 & 2 & 3 & 3 & 4 \\
\hline Czech Republic & 1 & 1 & 1 & 1 & 2 & 3 & 4 & 5 \\
\hline Denmark & 1 & 1 & 1 & 1 & 2 & 3 & 4 & 5 \\
\hline Estonia & 1 & 1 & 1 & 1 & 2 & 3 & 4 & 5 \\
\hline Greece & 1 & 3 & 4 & 5 & 2 & 3 & 4 & 5 \\
\hline France & 1 & 1 & 1 & 1 & 2 & 3 & 4 & 5 \\
\hline Italy & 1 & 1 & 1 & 1 & 2 & 3 & 4 & 5 \\
\hline Latvia & 1 & 1 & 1 & 2 & 2 & 3 & 4 & 5 \\
\hline Luxembourg & 1 & 1 & 1 & 1 & 2 & 3 & 4 & 5 \\
\hline Hungary & 1 & 1 & 1 & 1 & 2 & 3 & 4 & 5 \\
\hline Malta & 1 & 1 & 1 & 1 & 2 & 3 & 4 & 5 \\
\hline Netherlands & 1 & 3 & 3 & 4 & 2 & 3 & 4 & 5 \\
\hline Austria & 1 & 1 & 1 & 1 & 2 & 3 & 4 & 5 \\
\hline Slovenia & 1 & 1 & 1 & 1 & 2 & 3 & 4 & 5 \\
\hline Slovakia & 1 & 1 & 1 & 1 & 2 & 3 & 4 & 5 \\
\hline Finland & 1 & 1 & 1 & 1 & 2 & 3 & 4 & 5 \\
\hline Sweden & 1 & 1 & 1 & 1 & 2 & 3 & 4 & 5 \\
\hline United Kingdom & 1 & 1 & 1 & 1 & 2 & 3 & 4 & 5 \\
\hline Iceland & 1 & 1 & 1 & 1 & 2 & 3 & 4 & 5 \\
\hline Norway & 1 & 1 & 1 & 1 & 2 & 3 & 4 & 5 \\
\hline Serbia & 1 & 1 & 1 & 2 & 2 & 3 & 4 & 5 \\
\hline
\end{tabular}


Cluster sizes for years 2004 and 2015 were presented in Fig. 5. It turned out that the Polish and Lithuanians households' expenditure is similar to the Bulgarian and Romanian expenses. The Estonians and Latvians spending characteristics is similar to that of the Western Europeans. The most important vari-

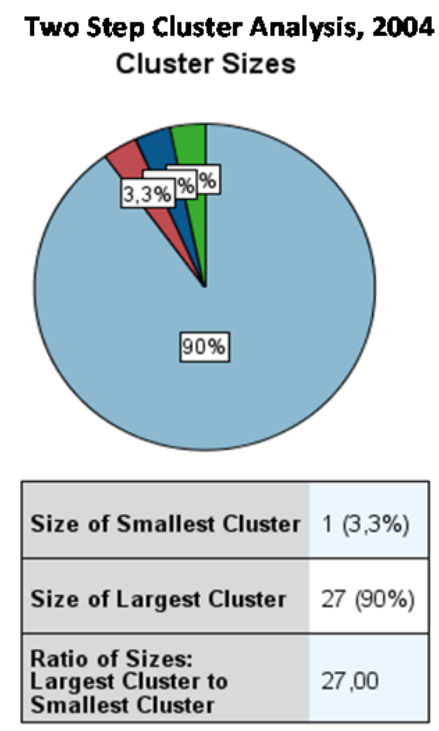

ables considered in the Two Step Cluster Analysis were "medical products, appliances and equipment" (predictor importance $=1$ ) and "hospital services" (predictor importance $=0.97$ ), whereas "outpatient services" was less important (predictor importance $=$ $0.35)$.

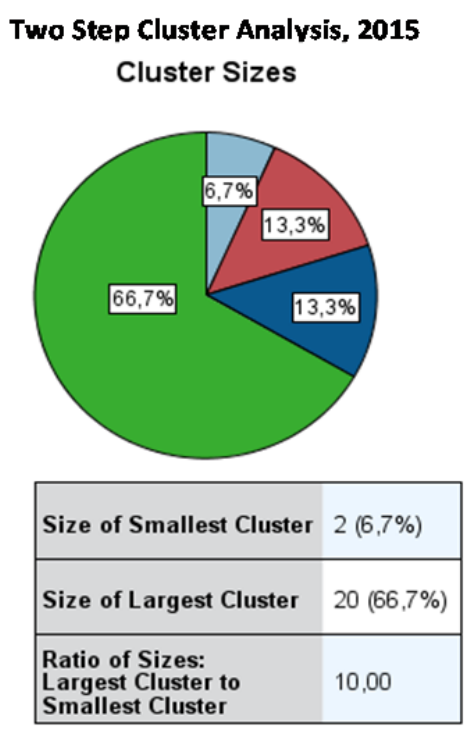

Figure 5. Clusters sizes according to Two Step Cluster Analysis for years 2004 and 2015 (Source: Authors' own research)

According to $\mathrm{K}$ Means Cluster Analysis, a nonhierarchical clustering approach, distinguishing four clusters was the best solution that was significant for the data of both years 2004 and 2015. The analysis required the use of variables with roughly equal amplitudes. Three variables: "medical products, appliances and equipment", "outpatient services" and "hospital services" used in the analysis had to be standardized and Z-values were taken for the analysis. According to ANOVA analysis, all variables were significant when creating the clusters ( $p$-value $<0.001$ ), however, looking at the difference of the cluster centers, the values "medical products" and "hospital services" were significantly different (p-value $<0.001$ for all clusters, both for year 2004 and 2015). "Outpatient services" centers for four clusters were not significantly different ( $\mathrm{p}$-value $>$ 0.8 for all clusters, both for year 2004 and 2015). Standardized cluster centers for years 2004 and 2015 are presented in the Fig. 6.

Centroid Linkage method was also used to classify the countries to the clusters. The results are presented in the Fig. 7. It turned out that the groups achieved were not meaningful. For year 2004, splitting the countries into two groups resulted in one cluster with one country, Belgium and the second cluster with all remaining countries, categorized into many subclusters. Even if the countries were divided into 5 clusters, the results were not satisfactory. Five countries belonged to one cluster and the rest to other three. Analysis performed for year 2015 gave similar results. Splitting the countries into 4 clusters produced three clusters of two and three countries and one big cluster with the remaining countries. The Centroid Linkage method was rejected due to the obtained results.

Another hierarchical cluster analysis taken into account was the Ward's method allowing splitting the countries into groups of similar size. Squared Euclidean distance was used during the analysis as a measure of proximity between groups. According to Ward's analysis (Table 4, Fig. 8), it was found that in 2004, all post-communist countries belonged to one common cluster, which confirms the existence of similar health care systems in those countries. After eleven years, in 2015, lateralization of groups 
has occurred. Latvia has joined the group of wealthy countries, where the health care expenditures represented a relatively small part of the home budget. The clusters to which Estonia, Poland and Lithuania belong to, health care spending has started to be recorded after 2004; since that time, the spending on medical products has risen significantly in Poland and Lithuania. This is due to smaller disposable in- come of the households and more accurate recording of expenditure.

It was found that Baltic countries in 2004 belonged to one group with other post-soviet countries like Romania, Slovakia and Czech Republic. Households in those countries were characterized by a high rate of whole medical expenses.
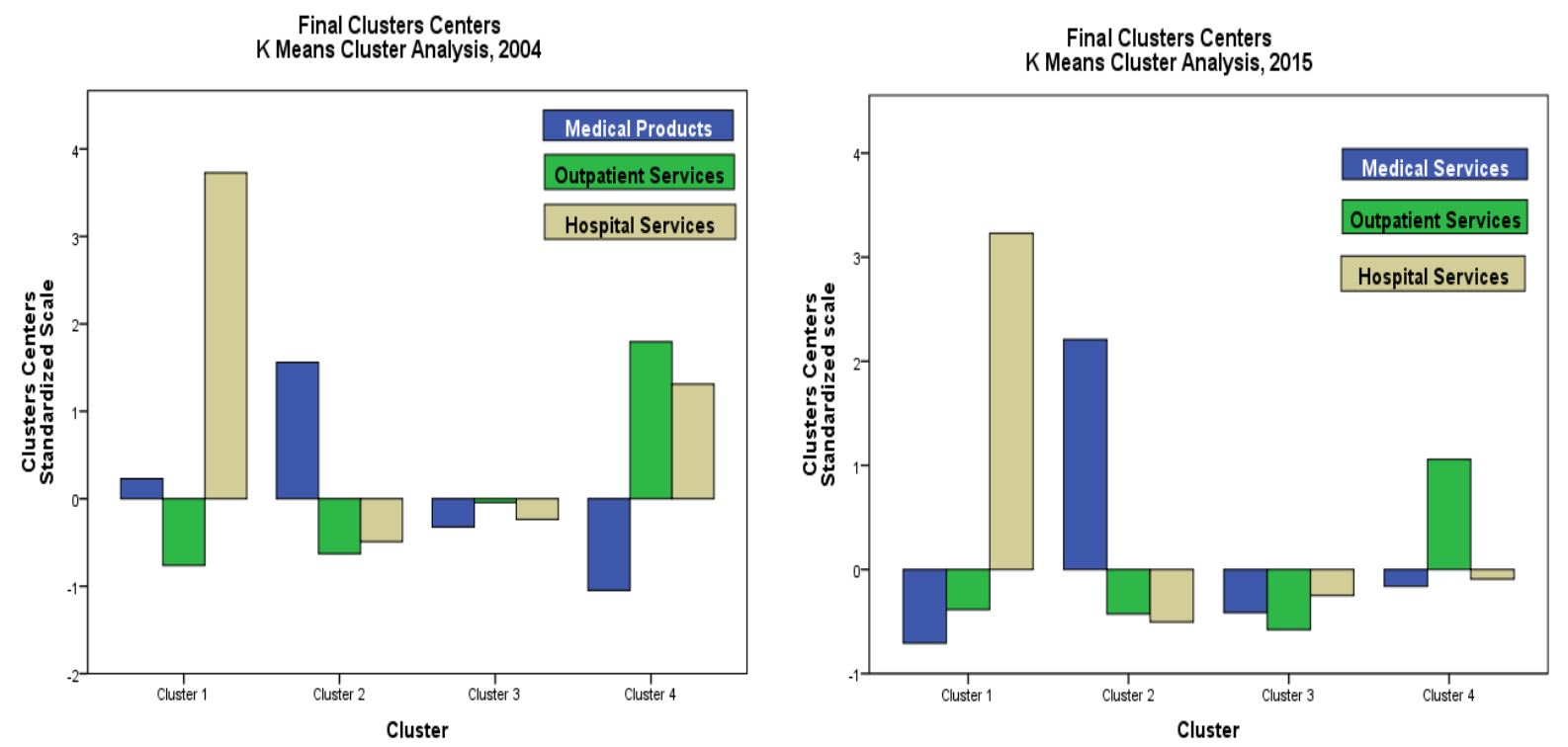

Figure 6. Clusters centers according to K Means Cluster Analysis on standardized scale for years 2004 and 2015 (Source: Authors' own research)
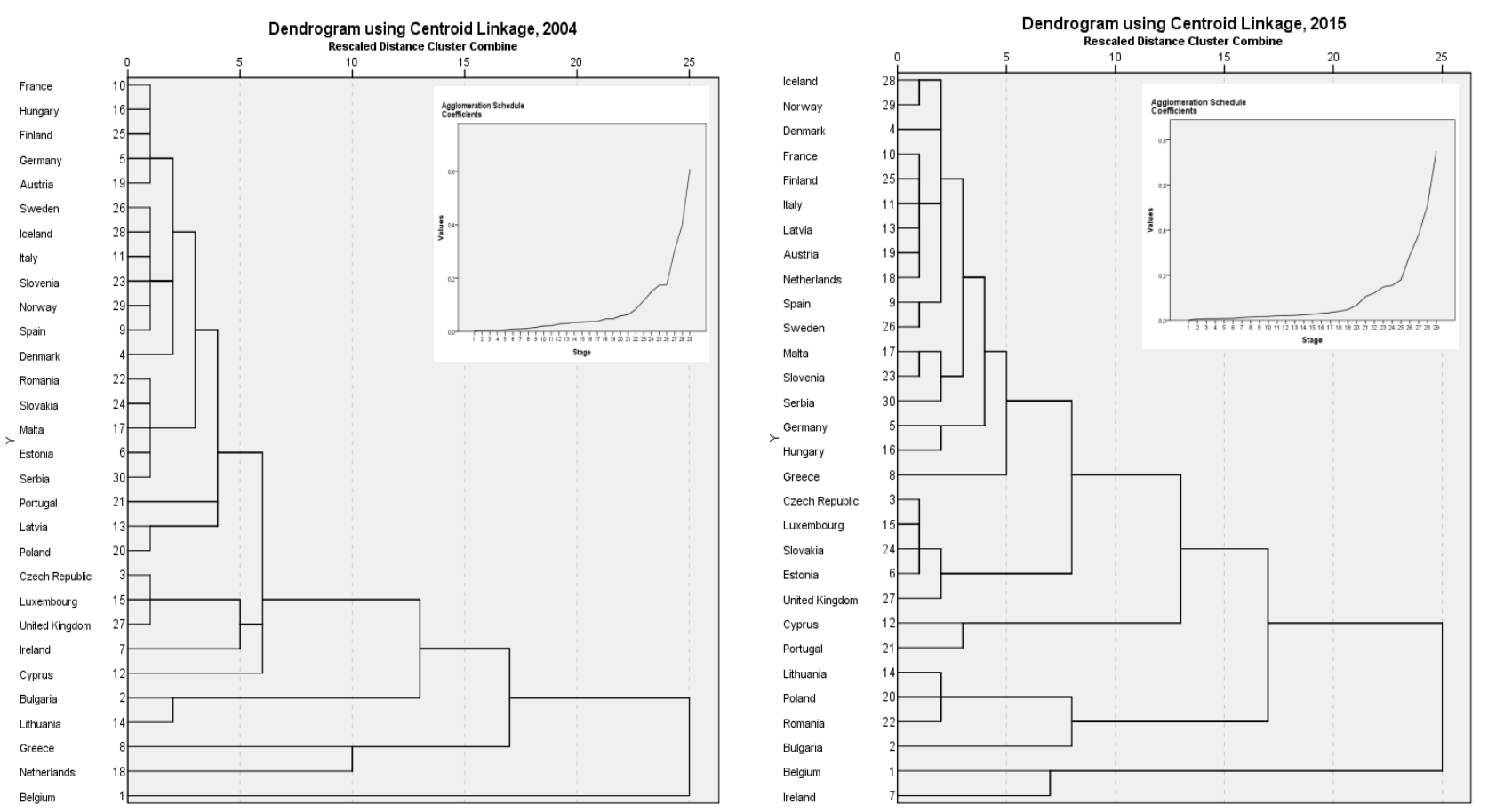

Figure 7. Clusters according to Centroid Linkage method for years 2004 and 2015. Inner graphs represent agglomeration schedule coefficients (Source: Authors' own research) 
Table 4. Cluster membership, Ward's analysis results for years 2004 and 2015

(Source: Authors' own research)

\begin{tabular}{|c|c|c|c|c|c|c|c|}
\hline \multirow{2}{*}{ UE Country } & \multicolumn{4}{|c|}{2004} & \multicolumn{3}{|c|}{2015} \\
\hline & $\begin{array}{c}2 \\
\text { clusters }\end{array}$ & $\begin{array}{c}3 \\
\text { clusters } \\
\end{array}$ & $\begin{array}{c}4 \\
\text { clusters }\end{array}$ & $\begin{array}{c}5 \\
\text { clusters } \\
\end{array}$ & $\begin{array}{c}2 \\
\text { clusters }\end{array}$ & $\begin{array}{c}3 \\
\text { clusters }\end{array}$ & $\begin{array}{c}4 \\
\text { clusters } \\
\end{array}$ \\
\hline Belgium & 1 & 1 & 1 & 1 & 1 & 1 & 1 \\
\hline Bulgaria & 2 & 2 & 2 & 2 & 2 & 2 & 2 \\
\hline Czech Republic & 2 & 3 & 3 & 3 & 1 & 3 & 3 \\
\hline Denmark & 2 & 3 & 4 & 4 & 1 & 3 & 4 \\
\hline Germany & 2 & 3 & 4 & 4 & 1 & 3 & 4 \\
\hline Estonia & 2 & 2 & 2 & 2 & 1 & 3 & 3 \\
\hline Ireland & 1 & 1 & 1 & 1 & 1 & 1 & 1 \\
\hline Greece & 1 & 1 & 1 & 5 & 1 & 1 & 1 \\
\hline Spain & 2 & 3 & 4 & 4 & 1 & 3 & 4 \\
\hline France & 2 & 3 & 4 & 4 & 1 & 3 & 4 \\
\hline Italy & 2 & 3 & 4 & 4 & 1 & 3 & 4 \\
\hline Cyprus & 2 & 3 & 4 & 4 & 1 & 3 & 4 \\
\hline Latvia & 2 & 2 & 2 & 2 & 1 & 3 & 4 \\
\hline Lithuania & 2 & 2 & 2 & 2 & 2 & 2 & 2 \\
\hline Luxembourg & 2 & 3 & 3 & 3 & 1 & 3 & 3 \\
\hline Hungary & 2 & 3 & 4 & 4 & 1 & 3 & 4 \\
\hline Malta & 2 & 2 & 2 & 2 & 1 & 3 & 4 \\
\hline Netherlands & 1 & 1 & 1 & 1 & 1 & 3 & 4 \\
\hline Austria & 2 & 3 & 4 & 4 & 1 & 3 & 4 \\
\hline Poland & 2 & 2 & 2 & 2 & 2 & 2 & 2 \\
\hline Portugal & 2 & 3 & 4 & 4 & 1 & 3 & 4 \\
\hline Romania & 2 & 2 & 2 & 2 & 2 & 2 & 2 \\
\hline Slovenia & 2 & 3 & 4 & 4 & 1 & 3 & 4 \\
\hline Slovakia & 2 & 2 & 2 & 2 & 1 & 3 & 3 \\
\hline Finland & 2 & 3 & 4 & 4 & 1 & 3 & 4 \\
\hline Sweden & 2 & 3 & 4 & 4 & 1 & 3 & 4 \\
\hline United Kingdom & 2 & 3 & 3 & 3 & 1 & 3 & 3 \\
\hline Iceland & 2 & 3 & 4 & 4 & 1 & 3 & 4 \\
\hline Norway & 2 & 3 & 4 & 4 & 1 & 3 & 4 \\
\hline Serbia & 2 & 2 & 2 & 2 & 1 & 3 & 4 \\
\hline
\end{tabular}

Eleven years later, costs of medical products, appliances and equipment still dominate in Estonia, Lithuania and Poland, while in Latvia, outpatient services have gained importance. Thus, the structure of health care expenditure in Latvian households has become similar to the structure of the countries such as Finland, France, Austria and Germany. Private health spending in Belgian households deserve special attention, where hospital services constitute the largest share in the structure of whole expenditure. 

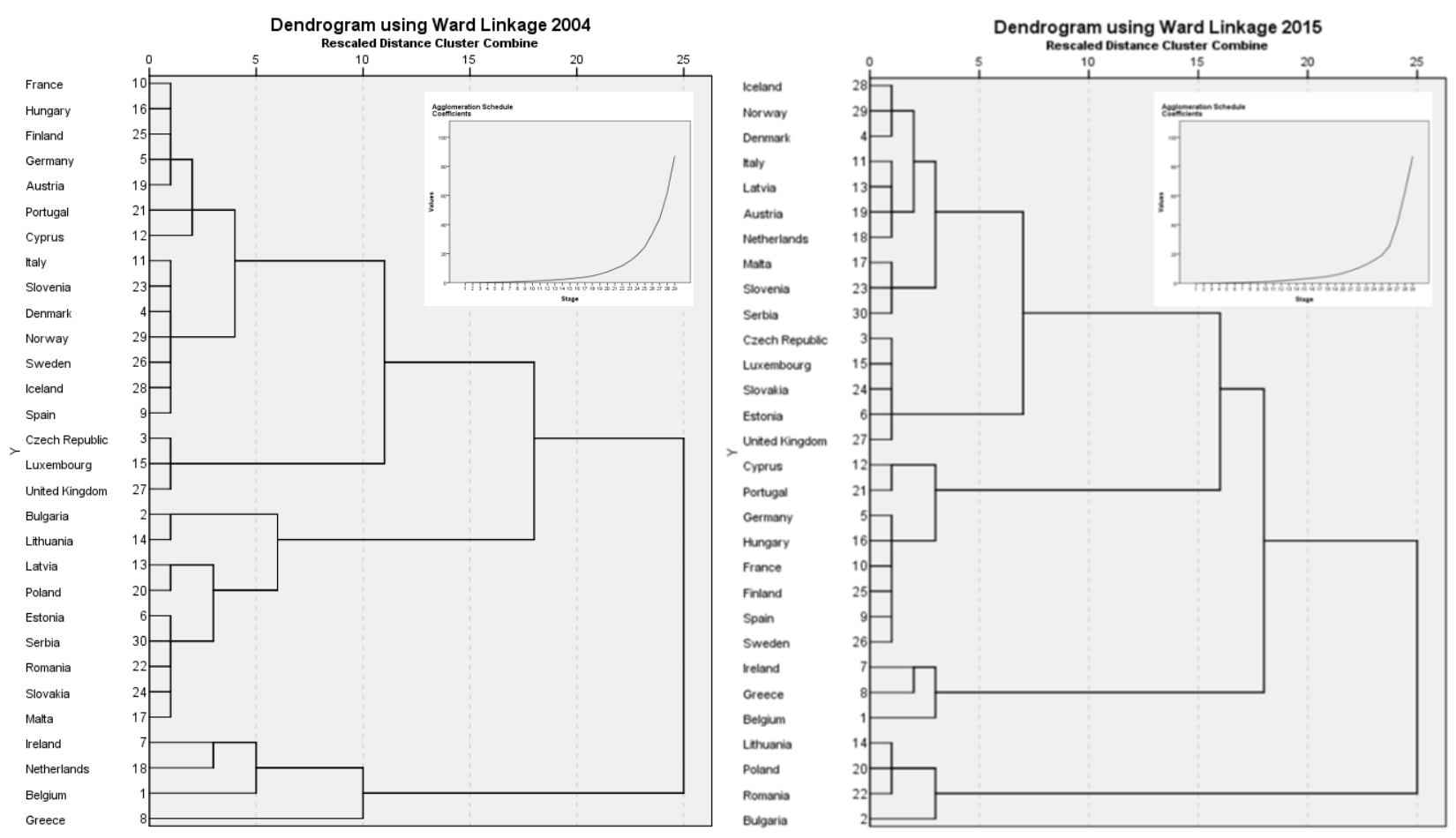

Figure 8. Clusters membership according to Ward's method for years 2004 and 2015. Inner graphs represent agglomeration schedule coefficients (Source: Authors' own research)

\section{Conclusions}

During the years $2004-2015$, a significant change has been recorded in the structure of health care expenditure in the Baltic Countries, where the influence of treatment services has increased, indicating that the share of health services in health care spending have grown significantly.

The smallest changes in the structure of health expenditure were recorded in the Polish households. Consumers' behavior in the medical services market are influenced by various economic, demographic and social factors. Presumably, Poland's basic obstacle to develop health care market is a shortage of household funds (Nieszporska, 2017).

The biggest changes were observed in the structure of health expenditure in relation to the expenditure on medical services. The largest increase of expenditure on medical services (in the structure of Baltic countries health expenditure) was recorded in Lithuania and Latvia. The increase of funds allocated in health care services is a consequence of growing health awareness of the society, demographic changes (aging of the population) and growing demand for health care services, which is a result of the population income growth.

Splitting countries into groups on the basis of health expenditure using different methods indicates that in 2004, the Baltic countries belonged to one group. A decade later, there was a diversification in the structure of health expenditure in the Baltic states. A polarization in the structure of health expenditure was observed in 2015. Lithuania and Poland belonged to one cluster, when Estonia and Latvia were a part of the other group. Large increase of the demand for healthcare services is associated with aging of the societies. It is necessary to support the increased demand for health care from private funds due to the limited possibilities of state's healthcare institutions.

Many variables affect changes in health expenditure, and one of these variables is suspected to be culture. In subsequent studies, it would be worth to examine the strength of the relationship between economic, demographic and socio-cultural factors with health expenditure in individual Baltic countries. It is strongly recommended to use the Structural Equation Modelling method; nonetheless, the research would require conducting surveys in each country. 


\section{References}

[1] Chen, J., Vargas-Bustamante, A., Novak, P., 2017. Reducing Young Adults' Health Care Spending through the ACA Expansion of Dependent Coverage. Health Services Research, 52(5), pp.1835-1857.

[2] European Commission, 2013. Study on Corruption in the Healthcare Sector.

[3] Eurostat, 2017. Health care expenditure by financing scheme. [online] Available at: $<\mathrm{http}$ //ec.europa.eu/eurostat/statistics-explain ed/index.php/Healthcare_expenditure_statistics $>$ [Accessed 19 Nov. 2017].

[4] Field, A., Miles, J. and Field, Z., 2013. Discovering Statistics Using SPSS. [online] Sage, London. Available at: $<$ http://sro.sussex.ac.uk/38823 $/ \% 5 \mathrm{Cn} ; \quad$ http://doi.wiley.com/10.1111/insr.120 $11 \_21>$.

[5] Gaile-Sarkane, E. ed., 2017. 58th The International Riga Technical University 'Scientific Conference on Economics and Entrepreneurship SCEE' 2017. [online] Available at: <http:// feem.rtu.lv/wp-content/uploads/sites/64/2016/04 /SCEE2017-Proceedings.pdf $>$.

[6] Głąbicka, K., 2012. The Protection of Health in the European Union. Studia Medyczne, 26(2), pp.93-105.

[7] Mitenbergs, U., Brigis, G., Quentin, W., 2014. Healthcare financing reform in Latvia: Switching from social health insurance to NHS and back? Health Policy, [online] 118, pp.147-152. Available at: <https://ac.els-cdn.com/S0 16885 1014002590/1-s2.0-S0168851014002590-main. pdf?_tid=530d3afe-dacf-11e7-b7e6-00000aab0f 27\&acdnat $=1512597144 \_5 c 43128190 \mathrm{acc} 422 \mathrm{~d} 2$ 74a8a38e5255d5> [Accessed 6 Dec. 2017].

[8] Nieszporska, S., 2017. Priorities in the Polish health care system. The European Journal of Health Economics, [online] 18(1), pp.1-5. Available at: <https://doi.org/10.1007/s10198-0160831-0>.

[9] O'Connor, J.S., Bankauskaite, V., 2008. Public health development in the Baltic countries (1992-2005): From problems to policy. European Journal of Public Health, [online] 18(6), pp.586-592. Available at: <https://academic.
oup.com/eurpub/article/18/6/586/580153/Publichealth-development-in-the-Baltic-countries>.

[10] OECD, 2017. Health at a Glance 2017. [online] Paris: OECD Publisher. Available at: $<$ http://dx.doi.org/10.1787/health_glance-2017en>.

[11] Mays, G.P., Mamaril, C.B., 2017. Public Health Spending and Medicare Resource Use: A Longitudinal Analysis of U.S. Communities. Health Services Research, 52, pp.2357-2377

[12] Przekota, G., Lisowska, A., 2016. The Reaction of Private Spending and Market Rates to the Changes in Public Spending. Foundations of Management, Vol. 8, No. 1, pp.203-210. http://doi.org/10.1515/fman-2016-0016.

[13] Szczepańska, K., Wiśniewska, M., 2012. Human Performance Improvement in the Health Care Organizations. Results of Empirical Study in Poland. Foundations of Management, Vol. 4, No. 2, pp.97-108. http://doi.org/10.2478/fman-20130013.

[14] Szetela P., 2016. Analiza finansowania ochrony zdrowia ze środków prywatnych w krajach europejskich należących do OECD. Optimum. Studia Ekonomiczne, [online] 4(82), pp.83-100. Available at: <http://repozytorium .uwb.edu.pl/ jspui/bitstream/11320/5240/1/07_Przemysław_S ZETELA.pdf> [Accessed 6 Dec. 2017].

[15] Tran, L.D., Zimmerman, F.J. Fielding, J.E. 2017. Public health and the economy could be served by reallocating medical expenditures to social programs. SSM - Population Health, 3, pp.185191.

[16] Ward, J.H., 1963. Hierarchical Grouping to Optimize an Objective Function. Journal of the American Statistical Association, Available at: $<$ http://iv.slis.indiana.edu/sw/data/ward.pdf $>$.

[17] World Health Organization, 2011. Polska: Zarys systemu ochrony zdrowia.

[18] World Health Organization, 2017. Global Health Expenditure Database. [online] Available at: $<$ http://apps.who.int/nha/database/ViewData/Ind icators/en> [Accessed 19 Nov. 2017].

[19] Yu, H., Greenberg, M., Haviland, A., 2017. The Impact of State Medical Malpractice Reform on Individual-Level Health Care Expenditures. Health Services Research, 52(6), pp.2018-2037. 